\title{
mHealth in Bangladesh: Current Status and Future Development
}

\author{
Mohammad Zahedul Alam \\ School of Management, Wuhan University of Technology \\ Associate Professor, Bangladesh University of Professionals \\ Email:zaheddu2000@yahoo.com
}

\begin{abstract}
Digital health has significant potential in health and health system potential. mHealth is one of the digital solutions, has been one of the focus in Bangladesh for the last couple of years. There is enormous potential in using mHealth within the healthcare sector to ensure healthcare quality, accessibility and affordability in developing countries including Bangladesh. A large number of people in developing countries, particularly in rural and remote areas, remained with no or little access to health care facilities. The private, public and NGOs sectors have motivated to spend a large budget on building mobile healthcare infrastructure throughout the country. The application of ICT to healthcare, especially mHealth, is rapidly advancing in Bangladesh. But, the current status of mHealth and way forward for future development in Bangladesh, however, has not been assessed. In the present study, we explored the state of the art of mHealth in the public, private and NGOs, as well as the technical and managerial challenges facing mHealth projects and future development in Bangladesh. This paper aims to make an overview of mHealth, identify needs for mobile health, present major mobile health in Bangladesh, and discuss ethical issues and challenges in mobile health development. Our findings revealed that although mHealth in Bangladesh remains somewhat challenging, it could be overcome. Based on the current scenario and challenges of mHealth, further development is required in the scope of some field. The findings of this study will help the stakeholders to make effective decisions regarding the mHealth services and future investment in this sector of Bangladesh.
\end{abstract}

Keywords: mHealth, Current Status, Challenges, Future development, Bangladesh etc.

\section{Introduction}

The world is becoming a service economy. ${ }^{1}$ Health care is one of the fastest growing sectors in this economy and this sector can be sustained through a critical evaluation of its impact on the success of stakeholders. ${ }^{2}$ In addition, sustainable development goals cannot be achieved when there is a high prevalence of debilitating illness. ${ }^{3,4,5}$ Health sector reform is not only a healthrelated issue but also a development issue. ${ }^{6}$ But this sector is facing serious challenges with a deadly combination of limited access to care, uneven quality and high costs. ${ }^{7,8}$ In this context, the application of mobile communications, creates the potential to transform health care delivery by making this service more accessible, affordable and available. ${ }^{9}$

Due to the delivery crisis, mobile health technologies have been proposed and implemented by various organizations to deliver healthcare services. ${ }^{10,11}$

Whereas, Digital-health, eHealth or mHealth has been developing rapidly in western and developed countries. Currently, about $85 \%-97 \%$ of the world's population has access to a mobile phone ${ }^{12,13}$. However, according to Newzoo's Global Market report, 2018, The number of active smartphones across the globe will top 3 billion in 2018 and hit 3.8 billion by 2021. Smartphone penetration of UAE is $82 \%$ (highest in the world), and $5.4 \%$ in Bangladesh.

It received important attention to providing effective health services. Whereas, mHealth has been emerged due to rapid growth in the use of mobile technologies and its connectivity to access health related information. ${ }^{14}$ mHealth has been successfully implemented in developed countries to access healthcare. ${ }^{15,16}$ On the other hand, the extensive functionalities of current smartphones, tablets and other devices allow the development of the mHealth application to thrive. ${ }^{17}$

In this context, mHealth is receiving attention as a potential solution to resolve the issue of limited access to healthcare and to satisfy the need to reduce healthcare costs. ${ }^{18}$ mHealth by virtue of its ubiquity and reach can serve even the remotest corners of a country and serving the un-served makes it a viable, scalable and dependable health care delivery platform. ${ }^{19,20,21,22 \& 23}$ 
In addition, eHealth is the blessing of ICT and has a major effect on improving the health care sector in developing countries. ${ }^{24}$

With these expected benefits of mHealth services, hundreds of projects have been proposed and are being undertaken globally. ${ }^{25}$

Like developed and other developing countries, Bangladesh is struggling to deliver affordable and accessible healthcare to all citizens in order to achieve sustainable development goals with limited resources and mass population. Surprisingly, Bangladesh is one of few countries in the world where public hospitals offer free medical services to all citizen at the community level. Currently, there are 607 government hospitals, 490 upazila and 1450 union levels hospitals and 127 secondary \& tertiary levels hospitals in Bangladesh. ${ }^{26}$ Furthermore, 5023 non-government hospitals are continuously working in Bangladesh. There are 20,603 registered doctor under DGHS. However, Bangladesh has been identified as one of 57 countries in the world with a critical shortage in health workforces (doctors, nurses and midwives number below 1.26 per 1000 population) and the number of beds (4 per 10,000) in hospitals. ${ }^{27}$ In addition, providing affordable and adequate health care is a challenge due to poor healthcare infrastructure and high population density. ${ }^{28}$ The overall health service consumption in Bangladesh is low in comparison to other developing countries, as is the level of need. ${ }^{29,30}$

On the other hand, different private healthcare organization has tried their best to provide better services to their patient along with government through ICT enable health services. ${ }^{31}$ In the light of resources shortages, the government has started a new era in the health sector by introducing ICT for health service delivery especially, mHealth is being promoted as a route to cost effective, equitable and quality healthcare in Bangladesh. mHealth is being introduced with the intention of improving healthcare delivery services. The Government has made a partnership with development partners, private organizations and NGOs to improve the quality, efficiency and safety of eHealth services in Bangladesh. ${ }^{32}$

However, most previous studies have only focused on the application of mHealth in Bangladesh in users' perspective. $^{33}$ No previous study has investigated current status and future development in Bangladesh. Therefore, this study will fill this gap for understanding better health services. the purpose of this study is to review the current status, challenges and future development of mHealth services in Bangladesh. The results produced in this research are on the literature of mHealth services in Bangladesh. This has been performed by the secondary sources based research and mHealth related research from 1998 to 2018. The author used the key words such as mHealth, eHealth, current status, challenges and future development to perform an overall search in the title or abstract of the article. Only credible secondary sources i.e. government source, reputed private organizations' report were examined. Whereas, multiple sources of data were used to verify the accuracy of the data.

This paper is composed of six sections: (1) An overview of mHealth (2) needs for mHealth in Bangladesh, (3) major mHealth products and technology in Bangladesh, (4) mobile and digital health services, (5) ethical issues related to mHealth, (6) challenges in mHealth development followed by conclusion and recommendations etc.

\section{2. mHealth}

mHealth is an abbreviation or mobile health, a term used for the practice of medicine and public health record supported by mobile devices such as mobile phones, tablet computers, wireless technologies and PDAs, for health services and information. ${ }^{34}$

mHealth is a component of eHealth and an emerging field in medical and public health. ${ }^{35}$ mHealth is defined as using the Internet and other technologies for releasing health information and services. ${ }^{36}$ In addition, mHealth is defined as the use of small, portable computers or telecommunications equipment to meet the needs of consumers about health care or health information services. ${ }^{37}$

mHealth is defined as the delivery of eHealthcare services via mobile technology Smartphone. This study focused only on the delivery of healthcare services via Smart phone.

$[$ mHealth $=$ Mobile $($ Smart $)$ phone + Healthcare Delivery Services].

While, Telemedicine is defined as delivery of Health services via mobile platform with clinical participation). eHealth is defined as the delivery of health services via ICT.

Broadly, mHealth is defined as the use of portable devices with the capability to create, store, retrieve and transmit data in real time between end-users and quality 
of care. ${ }^{22}$ mHealth is defined as the use of portable electronic devices for mobile voice and data communication over a cellular or other wireless network of base stations to provide health information. ${ }^{38}$ mHealth is identified as a new health care paradigm which is transforming health systems by increasing access, reducing costs, providing more timely and accessible information, and promoting consumercentered health care and well-being. ${ }^{39}$ In another recent study, mHealth is defined as the use of mobile phone and its different functionalities for providing various health care solutions. ${ }^{40}$

mHealth has emerged as an extended component of eHealth; however, it does not replace it and it provides personalized and tailored health care services. ${ }^{41}$ The following table 01 shows some unique attributes of mHealth services.

\begin{tabular}{|l|l|l|}
\hline \multicolumn{3}{|c|}{ Table 1 Unique Attributes of mHealth } \\
\hline \multicolumn{1}{|c|}{ Attributes } & \multicolumn{1}{|c|}{ Implications } & \multicolumn{1}{c|}{ Ref } \\
\hline Accessibility & $\begin{array}{l}\text { mHealth provides ubiquitous, } \\
\text { universal and unison accessibility } \\
\text { for any-time, anywhere solutions. }\end{array}$ & 32,43, \\
\hline $\begin{array}{l}\text { Personalized } \\
\text { Solutions }\end{array}$ & $\begin{array}{l}\text { mHealth provides individualized } \\
\text { solutions to address the specific } \\
\text { needs of a specific person based on } \\
\text { his/her profile }\end{array}$ & $44,45$. \\
\hline Immediacy & $\begin{array}{l}\text { mHealth provides right-time } \\
\text { services focusing on relevant, } \\
\text { targeted and timely information. }\end{array}$ & 45,46, \\
\hline $\begin{array}{l}\text { Location- } \\
\text { based } \\
\text { Information }\end{array}$ & $\begin{array}{l}\text { mHealth provides context-specific } \\
\text { information services using global } \\
\text { positioning systems (GPS) and cell } \\
\text { of origin (COO) technology. }\end{array}$ & 44,43, \\
\hline Interactivity & $\begin{array}{l}\text { mHealth creates value co-creation } \\
\text { through long-term and more } \\
\text { intense two-way interaction. }\end{array}$ & $\begin{array}{l}39,44, \\
38 .\end{array}$ \\
\hline Mobility & $\begin{array}{l}\text { mHealth serves the needs for } \\
\text { temporal, spatial and contextual } \\
\text { mobility. }\end{array}$ & $48,49$. \\
\hline
\end{tabular}

\section{Current Status}

Mobile health technology has promoted the development of teleconsultation. This particular platform is transforming health care delivery in developing countries by providing right-time medical services in terms of medical information, consultation, triage, diagnosis, referral, treatment and counseling (see Table 02).
mHealth in Bangladesh: Current Status, Challenges and Future Direction

\begin{tabular}{|c|c|}
\hline \multicolumn{2}{|c|}{ Table 2 mHealth Services in Bangladesh } \\
\hline $\begin{array}{l}\text { Medical } \\
\text { Information }\end{array}$ & $\begin{array}{l}\text { Availability and location of medical } \\
\text { facilities, such as, specialized doctors, } \\
\text { hospitals, clinics, laboratories or other } \\
\text { facilities. }\end{array}$ \\
\hline Triage & $\begin{array}{l}\text { Assessing patients on standard protocols } \\
\text { to determine whether they should be } \\
\text { directed to emergency, administration or } \\
\text { medical consultation services. }\end{array}$ \\
\hline Consultation & $\begin{array}{l}\text { Consulting on patients' conditions as a } \\
\text { first touch point of care. }\end{array}$ \\
\hline Diag & $\begin{array}{l}\text { Diagnosing health status after gathering } \\
\text { and analyzing health information. }\end{array}$ \\
\hline Referral & $\begin{array}{l}\text { Recommending patients for advanced } \\
\text { treatment such as an in-person } \\
\text { consultation with a physician at a clinic. }\end{array}$ \\
\hline Treatment & $\begin{array}{l}\text { Prescribing medications, prescribing care } \\
\text { by another health provider or prescribing } \\
\text { a plan of action for the patients based on } \\
\text { consultation. }\end{array}$ \\
\hline Counselling & $\begin{array}{l}\text { Supportive and encouraging counseling } \\
\text { to patients with specific mental or } \\
\text { physical ailments. }\end{array}$ \\
\hline
\end{tabular}

The high growth rate in access to telecommunications and ICT in Bangladesh, has the potential to address concerns related to the lack of healthcare services throughout the country. Six mobile phone operators function within the country, which includes Grameen Phone (GP), Banglalink, Robi, Airtel, Citycell and Teletalk. In addition, Mobile phone coverage had reached 98 per cent of all Bangladeshi adults. ${ }^{40}$

Mobile phone penetration rates stand at $96 \%$ globally; $128 \%$ in developed countries; and $89 \%$ in developing countries. ${ }^{50}$ In January, 2018, there are 147 million active subscribers and a calculated $13.8 \%$ annual growth rate and 9.05 crore internet users in Bangladesh. ${ }^{51}$ Though in Bangladesh, a number of initiatives relating to mHealth have been undertaken, still there is much lacking within the health sectors in Bangladesh. Developing and implementing mHealth apps thus can play vital roles to overcome this limitation to a great extent in Bangladesh, but still mostly the citizens of Bangladesh are not so aware of this service. ${ }^{52,13}$

In fact, mHealth is at the infant stage in the healthcare industry in Bangladesh. mHealth services have been evolved in the mid-1999. ${ }^{53}$ In July 1999, a mHealth link between the Centre for the Rehabilitation of the Paralyzed (CRP) in Dhaka and the Royal Navy Hospital, Haslar, UK have been established by the Swinfen Charitable Trust in the UK. ${ }^{54}$ Later in 2006, TRCL paired with Grameen Phone, country's largest telecom service provider to initiate a mobile phone 
based call center for subscribers. Other mobile phone operators are also providing medical advice and prescriptions to millions of callers in their networks at nominal fees.

In Bangladesh, a number of mHealth projects have been initiated, including the provision of primary healthcare, in disease surveillance and the collection of routine data, for health promotion and disease prevention initiatives. The current projects are summarized in (Table 3) including Government, Private, Mobile phone operators and NGOs. ${ }^{55}$

\begin{tabular}{|c|c|c|}
\hline \multicolumn{3}{|c|}{ Table 3 On Going mHealth Project in Bangladesh } \\
\hline mHealth themes & $\begin{array}{l}\text { Name of the } \\
\text { Projects }\end{array}$ & Modes of Delivery \\
\hline \multirow[t]{3}{*}{ Primary Healthcare } & $\begin{array}{l}\text { Ministry of } \\
\text { health and } \\
\text { family welfare }\end{array}$ & $\begin{array}{l}\text { SMS, Interactive } \\
\text { Voice Response } \\
\text { (IVR) }\end{array}$ \\
\hline & Health line 789 & $\begin{array}{l}\text { Telemedicine } \\
\text { Services }\end{array}$ \\
\hline & eClinic24 & $\begin{array}{l}\text { Telemedicine } \\
\text { Services, medical } \\
\text { hotline }\end{array}$ \\
\hline $\begin{array}{l}\text { Disease } \\
\text { surveillance and } \\
\text { data collection }\end{array}$ & $\begin{array}{l}\text { A longitudinal } \\
\text { study on the } \\
\text { epidemiology } \\
\text { of malaria in } \\
\text { Bandar ban } \\
\text { district, } \\
\text { Bangladesh }\end{array}$ & SMS, Phone Call \\
\hline \multirow[t]{3}{*}{$\begin{array}{l}\text { Health promotion } \\
\text { and disease } \\
\text { prevention }\end{array}$} & $\begin{array}{l}\text { Ministry of } \\
\text { Health and } \\
\text { Family welfare }\end{array}$ & SMS \\
\hline & $\begin{array}{l}\text { MAMA } \\
\text { (Aponjon) } \\
\text { project } \\
\end{array}$ & SMS, IVR \\
\hline & $\begin{array}{l}\text { Expanded } \\
\text { Programme on } \\
\text { Immunization } \\
\text { (EPI) }\end{array}$ & SMS \\
\hline $\begin{array}{l}\text { Health information } \\
\text { systems, toll-free } \\
\text { mobile phone } \\
\text { services for health } \\
\text { workers and point } \\
\text { of-care services }\end{array}$ & $\begin{array}{l}\text { Evaluation of } \\
\text { toll free mobile } \\
\text { phone } \\
\text { for maternal, } \\
\text { newborn and } \\
\text { child health } \\
\text { (MNCH) care }\end{array}$ & $\begin{array}{l}\text { Toll-free Mobile } \\
\text { phone }\end{array}$ \\
\hline \multirow[t]{2}{*}{ Research projects } & $\begin{array}{l}\text { Future Health } \\
\text { Systems }\end{array}$ & Teleconsultation \\
\hline & $\begin{array}{l}\text { Assessment of } \\
\text { community } \\
\text { readiness for } \\
\text { mHealth } \\
\text { intervention } \\
\end{array}$ & $\begin{array}{l}\text { Survey and in- } \\
\text { depth interviews on } \\
\text { existing uses of } \\
\text { mHealth and } \\
\text { services } \\
\end{array}$ \\
\hline
\end{tabular}

On October 17, 2012, The International Telecommunication Union (ITU) and WHO launched a new partnership called the 'mHealth' initiative to use mobile technology in order to provide healthcare services.

In 2011, WHO reported Bangladesh as one of the 15 countries using mHealth to raise health awareness. ${ }^{56}$ On the other hand, WHO reported that MoHFW reached 98\% of its target population through SMS on health education but did not provide messages in the mother tongue. $^{56}$

Numerous mHealth initiatives have been reported, and the mHealth knowledge repository cites some examples. Most of the cited project in the country was sponsored by the private, NGOs, Academic Institutions, and other funding institutions. Another survey in Bangladesh identified that more than 225 different eHealth and mHealth initiatives and projects since 1990. ${ }^{57}$

TRCL (Telemedicine Reference Center Ltd.) demonstrated successful medical call center system using mobile phone infrastructure and text messaging systems in 2005. At the end of the year 2009, TRCL launched chronic disease management system under "AMCARE" brand in Bangladesh. In the first phase, TRCL Diabetes Patient Management System (DPMS) and Mobile Applications were introduced. In following years, TRCL launched a pilot scheme in collaboration with ICDDR, B and JHSPH funded by DFID (UK) to include village doctors under medical call center system of TRCL. TRCL also launched medical call center service in Singapore for Bangladeshi expatriates. ${ }^{58}$ The government health services have established free teleconsultation with government doctors, SMS services for patient management and communication with staff. Unquestionably, in Bangladesh, mHealth is going to be a growing platform for healthcare services but in the adoption this services to the common people leftovers a challenge. $^{59}$

\subsection{Policy Initiatives}

Bangladesh has not yet been prepared to properly cope with the adoption of ICT in the health services sector. There are no specific rules and regulations for applying ICT efficiently and effectively in healthcare sector. However, the unavailability of evidence-based policy and management frameworks within national health strategies will be one of the most important challenges to the scaled adoption of mHealth services. In Bangladesh, the role of ICT depends on specific circumstances and some applications of ICT are more used than others. More systematic use of ICT in the 
health sector could be ensured through better planning, monitoring, and implementing of the government's health policies.

Different health programs using accessible mobile phone technology and innovative community-based health promotion methods have already commenced through the MoHFW.

Given its recent emergence into the telehealth field, policies governing the use of this technology are continually being shaped. The government's strategic policy guidelines for digital Bangladesh were highly appreciated by the global and national experts and one of its stated objectives is that "Quality healthcare will be provided to all citizens through the innovative application of ICT. ${ }^{60}$

The Government of Bangladesh is currently adopting an ambitious national strategy to incorporate ICTs into their health system, aligning with the Digital Bangladesh Vision 2021 where healthcare being one of the priorities on the list. ${ }^{61}$ In 2011, the Government of Bangladesh approved the 5-years long run Health, Population and Nutrition Sector Development Program (HPNSDP) 2011-2016 for the ministry of Health and Family Welfare (MoHFW). The HPNSDP 2011-2016 comprises 32 operational plans, of which one is the eHealth/mHealth. ${ }^{60}$

The objectives of the National ICT Policy - 2009 were social equity, productivity, integrity, education and research, employment generation, strengthening exports, healthcare, universal access, environment, climate and disaster management, and support to ICTs.

The government is implementing an ambitious strategy for integrating ICTs into the public health system. ${ }^{62}$ To implement the work both the government and development partners have agreed to develop a common framework, as well as funding. The government has also begun to establish a regulatory framework.

\section{2. mHealth initiatives in Government Hospitals}

The number of mHealth initiatives has increased rapidly since the first initiative in 1998. As reported in a recent study, currently, there are 26 mHealth projects run by public or private institutions with the aim of providing health services and/or managing health information. ${ }^{63}$

In May 2009, mHealth was established by the ministry of health in each of all upazila hospital and district hospitals of the country where a local call center will act for delivering medical advice as $24 / 7$ basis to the citizens. It has created opportunity, mainly for poor people living in rural areas to get medical advice. ${ }^{63}$ In March, 2010, Pregnancy Care Advice through SMS has launched in Bangladesh. This service is expected to contribute to the achievement of MDG 4 and 5 through improving neonatal and maternal health. ${ }^{64}$

The Telemedicine service was formally inaugurated on July 6, 2011 from the National Digital Innovation Fair. In 2012, ten more telemedicine centers in 10 different hospitals were opened. In 2013, another 10 new telemedicine centers were established in 10 different hospitals. ${ }^{65}$

The Information and Communications Technology (ICT) division under its 'Info Sarkar' project had launched 25 Telemedicine Centers at different upazila health complexes in January 10, 2015, to provide healthcare facilities to the rural people. Physicians and doctors of 11 medical university and college hospitals and institutions will provide advice and treatment regularly to the patients of rural areas at free of cost. Different types of modern tele-gadgets, including tele stethoscope, tele ophthalmoscope, tele spirometer, tele thermometer, tele ECG, tele BPG machine, tele pulse oximeter and tele microscope, and eight other kinds of modern equipment have been sent to 25 upazila health complexes to run these Telemedicine Centers. In addition, the government of Bangladesh is promoting the use of mobile phones in many sectors, including healthcare, as part of the 'Digital Bangladesh' vision by 2021. In Bangladesh, eHealth covers the development and use of a wide range of ICT systems for healthcare systems. Such as

- Electronic Health Record (HER or Electronic medical record/EMR)

- $\quad$ Telemedicine services

- $\quad$ Telemedicine service in community clinics

- $\quad$ Telemedicine service in the Union Information and Service Centre

- $\quad$ Complaints or suggestions through SMS

- $\quad$ Pregnancy care advice through SMS

- Health Statistics by SMS

- Hospital computerization

- $\quad$ Online Population Health Registry

- Human Resources Databases

- $\quad$ Online Processing of Dental Medical Admission Tests

- $\quad A D P$ Progress Monitoring System

- $\quad$ GIS in Health Service

- $\quad$ Schedule Management Software

- Bulk SMS 
- $\quad$ Digital training facility \& Internet connectivity in the health system

The MIS-DGHS, in coordination with the Ministry of Health and Family Welfare, is carrying out a partnership program with D.Net to provide a mHealth service called MAMA (Mobile Alliance for Maternal Action). MAMA Bangladesh uses a short code '16227', provides lifesaving information for pregnant women and new mothers, including also advice for their newborn babies and children through SMS and IVRs. This program is supported by USAID, partnered by Smiling Sun Clinic and Save the Children and coordinated by Associates and D.Net. ${ }^{62}$ As part of the government plan to develop an ICT-informed health system, a mobile phone health service which involves government-run upazila health complexes and district hospitals using mobile phones as a local 24/7-hour call Centre has been developed. The ministry of health and family welfare in Bangladesh is jointly planning with the World Bank to automate 300 public hospitals. Gradually, all hospitals will be automated. ${ }^{66}$

\section{3 mHealth Initiatives in Private Hospitals}

Currently, most of the private clinics and hospitals in the Dhaka City are using their own database system for patient health records. mHealth initiatives by Private sector in Bangladesh are remarkable. Because, various telecom firms, NGOs, and other private organizations are playing the significant role in providing mHealth. Majority of mHealth initiatives have been taken by Private hospitals in Bangladesh. The NGOs involved in the eHealth and mHealth sectors now include (i) the mobile telephone operators; (ii) for-profit and not-forprofit companies; (iii) producers and distributors of health-related commodities; (iv) service delivery NGOs which are integrating ICTs into their work; and (v) university research departments. The development of a wide variety of eHealth and mHealth innovations has been stimulated by funding from a number of channels which include bilateral support to NGOs, special donor programmes for supporting eHealth and mHealth, and challenge funds operated by large foundations.

\subsubsection{Telemeeting}

Apollo Hospitals Dhaka has introduced telemeeting service for the local patients across the country. This is a service through which the patients will attend a video conference with concern Consultants over skype as per their need. Patients are now able to avail doctor consultation of Apollo Hospitals Dhaka directly through this service being present at local information centers.

\subsubsection{Health Advice Lines}

Grameenphone, one of the large mobile phone operators in Bangladesh, launched the first telephone medical advice line in 2006, in collaboration with the Telemedicine Reference Centre (TRCL).

\subsubsection{Partnership with service providers}

In 2009, TRCL, in collaboration with the not-for-profit Diabetic Association of Bangladesh (DAB), established AMCARE, a subscription-based membership organization that aimed to use a telephone call center to encourage compliance with diabetes management protocols and provides a link to qualified doctors and nurses.

\subsubsection{Websites and text messages as sources of health information}

The Bangladesh Telecommunication Regulatory Commission (BTRC) has the power to request that mobile phone operators broadcast the government's SMS messages at no additional cost to the government or the mobile phone users. ${ }^{67}$

\subsubsection{The use of smartphones to enhance the capacity} of health workers

BRAC, a reputed NGOs, has introduced the use of smartphones in its Manoshi Project for improving slum dwellers' access to maternal, neonatal and child health. JiVitA is a long-term project of the Center for Human Nutrition of Johns Hopkins University. It operated in 19 unions in rural north-western Bangladesh and initiated a mCare programme in 2011, which combines mobile phone and database technologies to register and monitor pregnancies and neonatal and postnatal care.

On the other hand, Medinova Hospital has been operating a telemedicine service since 2007 that connects patients through video conferencing with physicians in India as follow up of treatment or assessment.

\subsection{6 mHealth Initiatives in Private Organizations and NGOs}

Private sector and mHealth initiatives in Bangladesh is remarkable because in the mHealth various telecom firms, NGOs, and other private organizations play significant role. A number of NGOs including BRAC, Sajida Foundation and D.Net subsequently developed an interest in eHealth. Later many private entities involved in telemedicine and/or patient record systems 
in their clinics and hospitals. According to a study conducted by the International Centre for Diarrheal Disease Research, Bangladesh (ICDDRB), till March 2012, a total of 26 initiatives (either pilot or full scale programs) with direct or indirect associations with eHealth and/or m-Health have been taken in Bangladesh, among which four were public, eighteen private and four NGOs. ${ }^{63}$

3.3.6.1 mCare: A pregnancy and neonatal health information system that connect rural health workers and facilities with pregnant women and their new born in Bangladesh., in partnership with Johns Hopkins University in the United States.

3.3.6.2 MAMA Bangladesh: Mobile Alliance for Maternal Action (MAMA), a global alliance for improving maternal and child health through mobile technology.

3.3.6.3 Aponjon mHealth service: Aponjon mHealth service, an initiative in Bangladesh by USAID under the patronage of Mobile Alliance for Maternal Action (MAMA), made a soft-launch after a successful pilot operation.

3.3.6.4 Manosh Innovation: Manoshi gained considerable traction using community health workers to aid poor women in child birth and neonatal healthcare. Currently piloted in the urban slums under Manoshi (MNCH Urban) Programme, the initiative intends to digitize the health services by collecting, recording, preserving household information thus creating a real time virtual database.

3.6.6.5 Mobile operator's mHealth Services: In Bangladesh, Grameenphone developed "789 Health-line Services" to all subscribers, Banglalink has recently launched "Healthlink Service". All Robi Customers can dial 789 and get connected to live call center agents who will be answering their health related queries and questions. In sum up, the following table 4 summarizes the eHealth/mHealth initiatives in Bangladesh.

\subsection{Ethical Issues Related to Mobile Health Services}

Mobile health systems may improve the quality of healthcare and patients' and family members' quality of life, they may also generate new security and privacy issues for patients. Those concerns have to be addressed before mobile health is widely adopted. The structure of the mobile health system includes three components: wearable sensors, smartphone, and web server. ${ }^{68}$ The

\begin{tabular}{|c|c|}
\hline $\begin{array}{l}\text { Managed } \\
\text { by Public }\end{array}$ & $\begin{array}{llr}\text { DGHS District Health Information } & \text { System } \\
\text { Version } 2 \text { (DHIS-2), DGHS Office Attendance } \\
\text { Monitoring System (OAMS), DGHS } \\
\text { Telemedicine, DGHS Mobile Phone } & \text { Health } \\
\text { Service (MPHS). } & & \\
\end{array}$ \\
\hline $\begin{array}{l}\text { Private } \\
\text { for Profit }\end{array}$ & $\begin{array}{l}\text { Medinova Telemedicine, eClinic24 (Chakaria } \\
\text { Project) by TRCL, AMCARE by TRCL, Health } \\
\text { services for expatriates in Singapore by TRCL, } \\
\text { Breast Cancer Finding via mobile by Amader } \\
\text { Gram, JBFH Telemedicine, Friendship by } \\
\text { mPower, MHSBC by mPower, Grameenphone } \\
\text { Health Line, Banglalink, Airtel, City cell, Robi, } \\
\text { TeleTalk etc. }\end{array}$ \\
\hline NGOs & $\begin{array}{l}\text { CRP Telemedicine, info LADY by DNet, } \\
\text { Aponjon (MAMA Bangladesh) by Dnet, BRAC } \\
\text { m-health etc. }\end{array}$ \\
\hline
\end{tabular}

smart phones store test results in the patient's electronic health records, which will be posted on web-based service site. The patient's doctor will get a notification to look at the test results and give the immediate feedback to the patient. Breach of privacy and confidential information may occur at any stage. On the other hand, patients are not willing to disclose their some physical or mental health problems. Furthermore, most patients with severe mental disorders requiring hospitalization are still admitted involuntarily by their family members. ${ }^{69}$ Furthermore, 55\% of apps tested in one study were found to send some of this information to other companies. ${ }^{70}$ All health services via mobile phone are also recorded automatically. So, this can pose a significant risk to user confidentiality if information were automatically released without the user's consent. In addition to confidentiality concerns, communication with clients via smartphones or other mobile devices involves several other ethical and policy issues. ${ }^{71}$

\subsection{Regulatory Issues and Policies}

Healthcare is a sensitive domain where people's lives are at risk. If some system is going to be used, proper procedures and rules are needed to be devised and followed to ensure safe practices of healthcare services otherwise it could lead to serious consequences. Although, the government of Bangladesh adopted a national ICT policy in 2009, it has not yet had any effect on hospitals. The regulatory/legal framework in Bangladesh has not yet been modernized to accommodate the growing needs of the electronic 
world. Still, an email has no official value and cannot be legally considered an acceptable mode of communication in government offices. There are no strong laws to protect against cyber-crime and laws for electronic authentication. ${ }^{72}$

In 2002, Bangladesh adopted a National Policy on ICTs which sought, by 2006, to develop a country-wide ICT infrastructure. ${ }^{73}$ Collectively, these developments have generated a lot of optimism about the potential of Bangladesh's telecommunication sector for addressing a range of development issues, including health. This is reflected in two recent documents, the National ICT Policy-200974 and the Outline Perspective Plan of Bangladesh 2010-2021 (Planning Commission 2010). The MoHFW has developed draft guidelines for Bangladesh e-health standards and an interoperability framework, to reduce duplication of effort and facilitate linkages among mHealth initiatives. So far, the guidelines focus on data collection and management. There has been much less progress on creating a regulatory framework with regard to nongovernment actors. To date, there are no agreed standards on the kinds of services a company can provide, the qualifications of people providing advice, the ownership of companies or the pricing policies. The global mHealth industry concluded that one of the biggest challenges for taking these services to scale is the negotiation of relationships between the telecoms and health sectors. ${ }^{75}$

The government can make this mHealth service more accessible by making the incoming phone calls of the given phone numbers free of call charge. It can be possible with the collaboration of telecom companies. This initiative will help the service seekers who have the complex health problem that may take a longer time to explain.

\section{Challenges}

Illiteracy, lack of English language proficiency, lack of trust and technological incapability were identified as barriers to use mHealth services in Bangladesh. ${ }^{16}$

Despite huge initiatives on health information and communication technologies implemented by the government of Bangladesh, the mHealth system still faces various challenges and constraints. ${ }^{76}$ Some of these include defining the service, standards across different organizations, financial viability, availability of technical staff, lack of common standards for health information and communication technologies leading to difficulties in data management and sharing among different databases and interoperability. Low speed internet connection in many remote areas and a high cost of infrastructure and integrated software development are also barriers to the implementation of mHealth services.

Bangladesh as well as other developing countries are facing various obstacles to the promotion and implementation of mHealth. This study has identified some major threats and challenges for developing mHealth in the developing world which include. ${ }^{4}$ Poor ICT infrastructure, Lack of appropriate IT policy, Lack of awareness of both government and citizens, Inadequate human resource capacity, Non-acceptability of IT systems, Lack of coordination, Low level of IT literacy, Lack of IT training, High-cost, lower liability of Internet access, Lack of education, Hassle in getting required service and Lack of information etc.

Some of the challenges identified by the National Health Policy (NHP)-2011 are: 1) weak management system, lack of materials and of quality in health service, 2) lack of people's awareness and quality service in case of maternity and child treatment, 3) lack of proper initiatives in controlling contagious diseases, 4) lack of proper initiative to control and prevent new diseases and viruses, 5) limited resources to control the diseases created for environmental consequences like dengue and malaria etc., 6) improper human resource development and management, 7) lack of research on health sector, 8) lack of people awareness in health sector, 9) improper implementation of health related laws, 10) lack of quality service provided by the hospitals, clinic and health related hospitals, and so on.

Bangladesh healthcare services sector faces numerous challenges for digitalization of this sector. ${ }^{75}$ The following table 5 shows different challenges on the basis of previous studies.

\begin{tabular}{|c|c|c|}
\hline Challenges & Description & References \\
\hline Inadequate ICT Infrastructure & Internet networks and electricity are not sufficient & 72 \\
\hline
\end{tabular}


mHealth in Bangladesh: Current Status, Challenges and Future Direction

\begin{tabular}{|c|c|c|}
\hline Financial Problems & Dependency on developed countries, foreign investors, World Bank and WHO. & 77 \\
\hline Resistance of Change & $\begin{array}{l}\text { Lack of motivation and encouragement regarding introducing and adopting new } \\
\text { ICTs. }\end{array}$ & 78 \\
\hline Usability \& User Acceptance & Unfamiliar, Unaware, Lack of Trust, Lack of Knowledge & 79 \\
\hline $\begin{array}{l}\text { Lack of Policy and } \\
\text { Regulations }\end{array}$ & $\begin{array}{l}\text { No modern legal framework and laws against cyber-crime and laws for electronic } \\
\text { authentication. }\end{array}$ & 72 \\
\hline $\begin{array}{l}\text { Lack of Technological Know- } \\
\text { how }\end{array}$ & $\begin{array}{l}\text { Less technical knowledges; lack of trust due to recent false report in the healthcare } \\
\text { sector. }\end{array}$ & 80 \\
\hline Interoperability of Systems & $\begin{array}{l}\text { No central database for citizen's access. The lack of interoperability and } \\
\text { standardization among systems. }\end{array}$ & 81 \\
\hline Leadership and governance & $\begin{array}{l}\text { No standard or widely accepted operational framework for eHealth or mHealth in } \\
\text { the country. }\end{array}$ & 63 \\
\hline Poor Health Knowledge & $\begin{array}{l}\text { Practices of healthy lifestyles and nutrition habits; health education and health } \\
\text { research; prevention programs etc. are negligible and, in many areas, absent in } \\
\text { Bangladesh. }\end{array}$ & 19 \\
\hline Corruption & $\begin{array}{l}\text { Corruption also prevails in the field of purchasing health materials i.e. food, } \\
\text { medicine, ambulance and health personnel etc. }\end{array}$ & 82 \\
\hline Policy Incoherence & $\begin{array}{l}\text { Some projects initiated by the government has been abandoned due to political } \\
\text { reason. Donor orchestrated reforms failed to earn public confidence and provide an } \\
\text { appropriate approach. }\end{array}$ & 80 \\
\hline $\begin{array}{l}\text { Monitoring and } \\
\text { Accountability }\end{array}$ & Lack of proper monitoring mechanism and system of accountability. & 80 \\
\hline Crisis in Personnel System & Lack of promotion prospects; Doctors are allowed to private practice. & 81 \\
\hline Poverty & $\begin{array}{l}\text { Poor people are neither capable of bearing their health expenditure nor conscious } \\
\text { of health, nutrition and sanitation. }\end{array}$ & 82 \\
\hline
\end{tabular}

The intention in this paper is to present an overview of the current state, challenges and future development of mHealth services by presenting the comprehensive review of the mHealth related articles appearing since 1998. Results were presented in terms of current status, challenges, policy initiatives, regulations etc. Like many other initiatives, Private institutions including the hospital, telecommunication organization, and NGOs are trying to providing different mHealth services to all citizens. Both government and private sectors are committed to provide health services using ICT. It has been observed that the community is somewhat ready in terms of technological readiness. However, inequity was observed in human resource readiness and technological capabilities. ${ }^{16}$

The analysis shows that the overall situation of digital health care services sector in Bangladesh is not up to the mark. The service recipients are not well-known to this innovation in healthcare services. However, despite the rapid increase of many wireless commercial services, the usage of mobile health services still remains very

\subsection{Theoretical and Practical Implications}

The findings have several theoretical implications. To the best of our knowledge, this is the first study, theoretically articulate the status, challenges and futute development of mHealth in the context of Bangladesh.

The study contributes to the field of knowledge regarding the mHealth status in a developing country especially in Bangladesh.

The findings of this study will be helpful for the policy makers and mHealth services providers while designing their campaign. mHealth can be considered as one of the potential and supportive systems within healthcare sectors in the developing countries to improve the access, efficiency, effectiveness, and quality of clinical and business processes utilized by healthcare organizations, practitioners, patients, and consumers in an effort to cheer up the health status of patients and to face emergency situations in some cases. 


\subsection{Limitations and Recommendations for future Research}

Adoption of mHealth is in its nascent stages in Bangladesh. For this reason, the development of local mHealth solutions, research on adoption, studies on usability should be more important.

This study has suggested some recommendations for developing a successful mHealth system. The policymaker and government agencies in Bangladesh should develop comprehensible national health policy to enable the acceptance of digital transformations in the healthcare sector. Fine guidelines should be prepared as early as possible which describes the standards and inter-operability procedures of the Health Information Systems Architecture. This study concludes that Bangladesh needs considerable preparation and planning to sustain eHealth and mHealth initiatives successfully.

\section{References}

1. Ostrom, A.L., Bitner, M.J., Brown, S.W., Burkhard, K.A., Goul, M., Daniels, V.S, Demirkan, H., \& Rabinovich, E. (2010). Moving forward and making a difference: research priorities for the science of service. Journal of Service Research, 13(1), 4-36.

2. Bitner, M.J., \& Brown, S.W. (2008). The service imperative business horizons, 51 (January-February), 39-46.

3. Saroj Mishra and Indra Pratap S, "mHealth: A Developing Country Perspective", Making the eHealth connection, Bellagio, Italy, July 13- August 8, 2008.

4. Jahan, S., \& Chowdhury, M. M. H. (2014). mHealth: A sustainable healthcare model for developing world. American Journal of Modeling and Optimization, 2(3), 73-76.

5. World Health Organization (WHO): The

World Health Report 2006 - Working together for health. 2006, Geneva: World Health Organization

6. Saka MJ, Isiaka SB, Akande TM, Saka AO, Agbana BE, Bako IA (2012). Health related policy reform in Nigeria: Empirical analysis of health policies developed and implemented between 2001 to 2010 for improved sustainable health and development. Journal of Public Administration and Policy Research. 2012; 4(3): 50-55.

7. Berry, L.L., \& Bendapudi, N. (2007). Healthcare: a fertile field for service research, Journal of Service Research, 10 (2), 111-122.

8. Porter, M.E., \& Teisberg E.O. (2006). Redefining health care: creating value based competition on results, Harvard Business School Press, Boston

9. Riley WT, Rivera DE, Atienza AA, et al. (2011).
Medical device regulators need to consider alternative ways of evaluating the safety and reliability of mHealth services. Clear leadership and supportive policy actions will be required if the full potential for mobile health is to be realized.

In this respect, it can be concluded that services providers have to build a quality ICT based health service that must be easily and widely available throughout the country. Additional formative and operational research is essential to explore the true potential of technology. Frameworks for regulation in regards to eHealth governance should be the aim of future research on the integration of eHealth and mHealth into the Bangladesh health system. Researchers can conduct research on eHealth, mHealth, telecare, telehealth, electronic health record, telemedicine and video conferencing separately etc.

Health behavior models in the age of mobile interventions: are our theories up to the task? Transl Behav Med, 2011;1(1):5371

10. Consulting VW. m-Health for development: The opportunity of mobile technology for healthcare in the developing world. Washington DC and Berkshire, UK: UN Foundation-Vodafone Foundation Partnership, 2009.

11. Donker, T., Petrie, K., Proudfoot, J., Clarke, J., Birch, M.R., Christensen, H., 2013. Smartphones for smarter delivery of mental health programs: a systematic review. J. Med. Internet Res. 15 (11), PMID: 24240579

12. Sanou, B., 2013. The World in 2013: ICT Facts and Figures.

http://www.itu.int/en/ITUD/Statistics/Documents/facts/ICTFa ctsFigures 2013-e.pdf (retrieved 22.05.14).

13. Karim, M. M., Islam, M. N., Priyoti, A. T., Ruheen, W., Jahan, N., Pritu, P. L., . . . Duti, Z. T. (2016). Mobile health applications in Bangladesh: A state-of-the-art. Paper presented at the Electrical Engineering and Information Communication Technology (ICEEICT), 2016 3rd International Conference on.

14. Hoque, M. R., Bao, Y., \& Sorwar, G. (2017). Investigating factors influencing the adoption of e-Health in developing countries: A patient's perspective. Informatics for Health and Social Care, 42(1), 1-17.

15. Lewis, Trevor; Christina Synowiec; Gina Lagomarsino; and Julian Schweitzer (2012). E-health in Lowand Middle-income Countries: Findings from the Center for Health Market Innovations. Bulletin of the World Health Organization, Vol. 90, No. 5 (May), pp. 332- 340; available at: http://www.who.int/bulletin/volumes/90/5/11-099820.pdf. 16. Khatun F, Heywood AE, Ray PK, Hanifi SM, Bhuiya 
A, Liaw ST. Determinants of readiness to adopt m-Health in a rural community of Bangladesh. Int J Med Inform 2015; 84:847-856.

17. Lee, S., \& Kim, B. G. (2017). The impact of qualities of social network service on the continuance usage intention. Management Decision, 55(4), 701-729

18. Lee, E., \& Han, S. (2015). Determinants of adoption of mobile health services. Online Information Review, 39(4), 556-573.

19. Akter S, D’Ambra J, Ray P. User perceived services quality of mHealth Services around the world. In the proceedings of the $18^{\text {th }}$ European Conference on Information Systems, Pretoria, South Africa, 2010

20. Ivatury, G., J. Moore, et al. (2009). "A Doctor in

Your Pocket: Health Hotlines in Developing Countries." Innovations: Technology, Governance, Globalization 4(1): 119-153.

21. Mechael, P. N. (2009). "The Case for mHealth in Developing Countries." Innovations: Technology, Governance, Globalization 4(1): 153-168.

22. Vital Wave Consulting (2009). mHealth for

Development: The Opportunity of Mobile Technology for Healthcare in the Developing World. Washington, D.C. and Berkshire, UK: UN Foundation-Vodafone Foundation Partnership, 2009

23. Bashshur, R., G. Shannon, et al. (2011). "The Taxonomy of Telemedicine." Telemedicine and eHealth 17(6): 484-494.

24. Ginsburg, O. (2014). The promise and pitfalls of global mHealth. CMAJ, 186(15).

25. Labrique, A., Vasudevan, L., Chang, L.W. and Mehl, G. (2013), “ H_pe for mHealth: more y or o on the horizon?:, International Journal of Medical Informatics, Vol.82 No.5 pp.467-469.

26. BBS, (2017). Bangladesh Bureau of Statistics, Ministry of Planning, Dhaka, Bangladesh

27. DGHS (2011). eHealth. Retrieved June 29, 2013, from Directorate General of Health Services (DGHS):

28. Mostafa, R., Ehsanur Rahman, GMA., Hasan, G.M., Kabir, A., Rahman, A. \& Ashik, S. (2010). Proposed Deployments to provide E-Healthcare in Bangladesh: Urban and Rural Perspectives. $12^{\text {th }}$ IEEE International Conference on eHealth Networking Applications and Services.

29. Ahmed SM: Exploring health-seeking behavior of disadvantaged populations in rural Bangladesh. PhD Thesis. 2005, Karolinska Institute University, Deptt. Of Public Health Sciences, [http://diss.kib.ki.se/2005/91-7140-435-X/]

30. Mercer AJ, Hossain S, Khatun J, Kabir H, Saha N,

Uddin J, Hassan Y: Screening for service needs in Primary Health Care clinics: an evaluation in Bangladesh. J Health Popul Developing Countries. [http://www.jhpdc.unc.edu].

31. BDF (2010). Digital Bangladesh for Good governance, Bangladesh Development Forum, The Government of the People's Republic of Bangladesh.

32. World Health Organization (2012). World health statistics 2012. World Health Organization.

33. Joshua D. Cameron, Arkalgud Ramaprasad, Thant
mHealth in Bangladesh: Current Status, Challenges and Future Direction

Syn (2017), An ontology of and roadmap for mHealth research, International Journal of Medical Informatics, 100 (2017) 16-25

34. Shaw, R. J., Steinberg, D. M., Bonnet, J., Modarai, F., George, A., Cunningham, T., . . Bennett, G. G. (2016) Mobile health devices: will patients actually use them? Journal of the American Medical Informatics Association, 23(3), 462466.

35. Fiordelli, M., Diviani, N., \& Schulz, P. J. (2013).

Mapping mHealth research: a decade of evolution. Journal of medical Internet research, 15(5).

36. Gustafson, D. H., \& Wyatt, J. C. (2004). Evaluation of ehealth systems and services: We need to move beyond hits and testimonials. BMJ: British Medical Journal, 328(7449), 1150 .

37. Chen, H., 2012. A Study of Mobile Internet Regional Collaboration and Cardiovascular Emergency Treatment Mode. Third Army Medical School, Chong Qing, China.

38. Kahn, J.G., Yang, J.S. and Kahn, J.S. (2010), ”Mobile

health needs and opportunities in devleoping countries", Health Affairs, Vol.29 No.2, pp.252-258

39. Earth Institute. (2010). Barriers and gaps affecting mHealth in low and middle income countries: a policy white paper. Washington, mHealth Alliance, D.C.

40. WHO (2011). World Health Organizations

41. Darrell M. West, "Using mobile technology to improve maternal health and fight Ebola: A case study of mobile innovation in Nigeria," CFTI, 2015 [On-Line]. Available: http://www.brookings.edu [Accessed July 1, 2015] 42. Bauer, H.H., Barnes, S., Reichardt, T. \& Neumann, M.M. (2005). Driving consumer acceptance of mobile marketing: A theoretical framework and empirical study. Journal of Electronic Commerce Research,6(3), 181-192.

43. Varshney, U. (2009). Pervasive healthcare

computing: EMR/EHR, wireless and health monitoring. Springer Science \& Business Media.

44. Barnes, S.J. (2003). Location-Based Services: The State-of-the-Art, e-Service Journal, 2(3), 59-70.

45. Barnes, S.J. and Scornavacca, E. (2004). Mobile Marketing: The Role of Permission and Acceptance, International Journal of Mobile Communications, 2(2), 128139.

46. Barwise, P. \& Strong, C. (2002). Permission-based Mobile Advertising. Journal of Interactive Marketing,16 (1), 14-24.

47. Pousttchi, K. \& Wiedemann, D.G. (2010). Mobile marketing management: marketing objectives, types and implementation techniques, Handbook of Research on Mobile Marketing Management, (Eds.) Key Poustchhi \& Dietmer G. Widemann, IGI publishing, Cambridge, USA 2009, 1-09. 
48. Kakihara, M. \& Sorensen, C. (2001). Expanding the 'mobility' concept, ACM SIGGROUP Bulletin, 22(3).

49. Chatterjee, S., Chakraborty, S., Sarker, S., Sarker, S., \& Lau, Y.F. (2009). Examining the success factors for mobile work in healthcare: a deductive study. Decision Support Systems, 46, 620-633.

50. International Telecommunication Union (ITU), Geneva, Switzerland, The World in 2013: ICT Facts and Figures, http:॥www.itu.int/ict (visited on May 30, 2014).

51. BTRC (2018). Internet Subscribers in Bangladesh, Bangladesh Telecommunication Regulatory Commission Report

52. Vatsalan, D., Arunatileka, S., Chapman,

K.,Senaviratne, G., Sudahar, S., Wijetileka, D., \& Wickramasinghe, Y. (2010). Mobile technologies for enhancing eHealth solutions in developing countries. Paper presented at the eHealth, Telemedicine, and Social Medicine, 2010. ETELEMED'10. Second International Conference on.

53. Nessa A. Ameen MA Ullah S, Kwak K (2010):

Applicability of Telemedicine in Bangladesh current status and future prospects. The International Arab Journal of Information Technology 7:2.

54. Vassallo, D. J., Swinfen, P., Swinfen, R., \& Wootton, R. (2001). Experience with a low-cost telemedicine system in three developing countries. Journal of telemedicine and telecare, 7(1_suppl), 56-58.

55. Bloom, G., Sarwar, R., Standing, H., Begum, T., Rahman, S., \& Wilkinson, A. (2013). Innovations for Health in Bangladesh. Report to DFID-funded Srijon.Project.http://srijon.grminternational.com/wpcontent/up loads/2014/03/Srijon-scoping-study.pdf

56. M. Kay. mHealth: New horizons for health through mobile technologies. World Health Organization (2011).

57. Ahmed T, Bloom G, Iqbal M, et al. E-health and Mhealth in Bangladesh: opportunities and challenges. Evidence Report Brighton, UK: Institute of Development Studies, 2014.

$$
58 . \quad \text { R. S. H. }
$$

Istepanian and Jovanov, "Guest editorial introduction to the special section on m-health: Beyond seamless mobility and global wireless health-care connectivity," IEEE Transactions on Information Technology in Biomedicine, vol. 8, issue 4, pp. 405-415, December 2004.

59. Hoque, M. R., Albar, A., \& Alam, J. (2016). Factors influencing physicians' acceptance of e-health in developing country: An empirical study. International Journal of Healthcare Information Systems and Informatics (IJHISI), 11(1), 58-70.

60. UNDP (2010). Strategic Priorities of Digital
Bangladesh, Access to Information and United Nations Development Programme, October.

61. Birdsall K. A Quiet Revolution: Strengthening the Routine Health Information System in Bangladesh. Deutsche Gesellschaft für International Zusammenarbeit (GIZ) Eschborn, Germany. 2014.

62. Azad, A.H. (2013) 'Taking eHealth \& mHealth to National Scale in a Resource Poor Setting: Bangladesh as an Example', PowerPoint presentation to Johns Hopkins School of Public Health, 8 February 2013

63. Ahmed T, Lucas H, Khan AS, et al. eHealth and mHealth initiatives in Bangladesh: a scoping study. BMC Health Serv Res 2014; 14:260.

64. DGHS, (2011). Directorate General of Health Services.http://

dghs.gov.bd/bn/licts_file/images/eHealth/our_eHealth_ Aug_2011.pdf.

65. Health bulletin (2013). Management Information System. Directorate General of Health Services. Ministry of Health and Family Welfare. Government of the People's Republic of Bangladesh. Available from: www.dghs.gov.bd 66. DGHS

(2011). eHealth. Retrieved June 29, 2018, from Directorate General of Health Services (DGHS): http://www.dghs.gov.bd/en/index.php/e-Health-ict-healthservice/174-hospital-automation-process.

67. World Health Organization (2012). World health statistics, 2012. World Health Organization.

68. Zhou, T. "Examining Location -Based Services Usage from the Perspectives of Unified Theory of Acceptance and Use of Technology and Privacy Risk," Journal of Electronic Commerce Research, Vol.13, No.2:135-144, 2012 69. Phillips, M.R., Chen, H.H., Diesfeld, K., Xie, B., Cheng, H.G., Mellsop, G., Liu, X.H., 2013. China's new mental health law: reframing involuntary treatment. Am. J. Psychiatry 170, 588-591.

70. Thurm, S., \& Kane, Y. I. (2010). Your apps are watching you. Wall Street Journal. Retrieved fromhttp://online.wsj.com/article/SB10001424052748704694 004576020083703574602.html.

71. Luxton, D. D., McCann, R. A., Bush, N. E., Mishkind, M. C., \& Reger, G. M. (2011). mHealth for mental health: Integrating smartphone technology in behavioral healthcare. Professional Psychology: Research and Practice, 42(6), 505-512. doi:10.1037/a0024485.

72. Uddin, G (2012). E-governance of Bangladesh: 
Present Scenario, Expectation, Ultimate Target and Recommendation, International Journal of Scientific \& Engineering Research, 3(1), 11, ISSN 2229-5518

73. Ministry of Health and Family Welfare, Government of the People's Republic of Bangladesh, Health, Population and Nutrition Sector Development Program (2011-2016), Program Implementation Plan in: Ministry of Health and Family Welfare, Government of the People's Republic of Bangladesh (Eds.) Dhaka, Bangladesh 2011.

74. Science and Information, Communication

Technology Ministry, National Information and Communication Technology Policy 2009, Science and Information and Communication Technology Ministry, Government of Bangladesh Dhaka, Bangladesh, 2009.

75. Qiao, C.; Yamamichi, M.; Hausman, V.; Miller, R.

and Altman, D. (2012) Mobile Applications for the Health Sector, Washington DC: ICT Sector Unit, World Bank

76. Stanberry B. Telemedicine: barriers and opportunities in the $21^{\text {st }}$ century. J Intern Med 2000; 247:61528.

77. Hoque, M. R. (2016). An empirical study of mHealth adoption in a developing country: the moderating effect of gender concern. BMC medical informatics and decision making, 16(1), 51.

78. Hoque, R., \& Sorwar, G. (2017). Understanding factors influencing the adoption of mHealth by the elderly: an extension of the UTAUT model. International journal of medical informatics, 101, 75-84.

79. Hoque, M. R., \& Bao, Y. (2015). Cultural influence on adoption and use of e-Health: evidence in Bangladesh. Telemedicine and e-Health, 21(10), 845-851.

80. Alam, J. E-Governance in Bangladesh: Present Problems and Possible Suggestions for Future Development. International Journal of Applied Information Systems (IJAIS). 2012, 4(8):107-119

81. Gao, X., Xu, J., Sorwar, G.\& Croll P. Implementation of E-Health Record Systems and E-Medical Record Systems in China. The International Technology Management Review, 2013:3(2): 127-139

82. Islam M. Shafiqul (2015). Introducing modern technology to promote transparency in health services. International Journal of Health Care Quality Assurance, 2015. 28(6): 611-620. 